\title{
PERSEPSI PASIEN DAN PERAWAT TENTANG PATIENT SAFETY DI PELAYANAN HEMODIALISA
}

\author{
Dewi Kusumastuti ${ }^{1}$, Oryzati Hilman ${ }^{2,}$ Arlina Dewi ${ }^{3}$ \\ Universitas Muhammadiyah Yogyakarta ${ }^{1,2,3}$ \\ dewi.kusumastuti.pasca17@ mail.umy.ac.id ${ }^{1}$
}

\begin{abstract}
ABSTRAK
Penelitian ini bertujuan untuk menggali persepsi pasien dan perawat terhadap patient safety sebagai upaya meningkatkan Patient engagement sehingga pasien dapat awarness terhadap keselamatan pasien di Unit Hemodialisa Rumah Sakit. Metode penelitian ini menggunakan metode kualitatif melakukan wawancara mendalam kepada pasien dan tenaga medis. Hasil dari penelitian ini menunjukkan bahwa secara keseluruhan pasien mengatakan puas dengan pelayanan yang diberikan, hal ini dibuktikan dengan pasien merasa sangat dikenal oleh tenaga medis baik dengan perawat maupun dokter. Simpulan, hubungan kekeluargaan ini sangat dihargai oleh pasien dan keluarga pendamping, sehingga pasien dapat terbuka dengan tenaga medis, sehingga komunikasi efektif dapat terjalin dengan baik.
\end{abstract}

Kata Kunci: Hemodialisa, Patient Engagement, Patient Safety

\section{ABSTRACT}

This study aims to explore patient and nurse perceptions of patient safety to increase patient engagement so that patients can be aware of patient safety in the Hospital Hemodialysis Unit. This research method uses qualitative methods of conducting indepth interviews with patients and medical personnel. The results of this study indicate that overall the patients said they were satisfied with the services provided; this was evidenced by the patient feeling very well known by the medical staff, both nurses and doctors. In conclusion, this kinship relationship is highly valued by the patient and accompanying family so that patients can be open to medical personnel so that effective communication can be well established.

Keywords: Hemodialysis, Patient Engagement, Patient Safety

\section{PENDAHULUAN}

Keamanan dan keselamatan pasien merupakan hal penting dan mendasar yang perlu diperhatikan oleh tenaga medis. Rumah sakit merupakan organisasi kesehatan yang memiliki resiko tinggi terhadap insiden keselamatan pasien (Buku Pedoman Keselamatan Pasien RSPP). Mulyati dalam Wulandari menyatakan bahwa, kesalahan terhadap patient safety sering disebabkan oleh kesalahan manusia, hal ini disebabkan oleh kegagalan sistem dimana individu tersebut bekerja, oleh karena itu perlu dibentuknya sebuah sistem terkait pengenalan resiko, identifikasi resiko, serta pengelolaan resiko, sebagai tindak lanjut dan implementasi solusi untuk meminimalkan resiko-resiko tersebut (Wulandari et al., 2020). 
Pelayanan kesehatan merupakan suatu sistem yang sangat kompleks dan memiliki banyak multiple stakeholder dan providers. Pasien merupakan orang yang menggunakan layanan kesehatan berupa jasa medis yang memiliki peranan penting sebagai coproducer kesehatan. Pasien merupakan informan penting dalam perbaikan kebijakan, sehingga mengajak pasien berkontribusi merupakan suatu cara yang signifikan untuk dapat meningkatkan patient safety dan kualitas pelayanan kesehatan. Istilah keterlibatan pasien mengacu pada proses membangun dan memfasilitasi pasien untuk mendukung keterlibatan aktif pasien dalam perawatan kesehatan mereka sendiri (Valderas et al., 2019).

Setiap tindakan pelayanan kesehatan yang diberikan kepada pasien sudah sepatutnya memberikan dampak yang postif terhadap pasien. Oleh karena itu, rumah sakit harus memiliki standar dalam memberikan pelayanan kepada pasien. Standar tersebut bertujuan untuk melindungi hak pasien dalam menerima pelayanan kesehatan serta sebagai pedoman bagi tenaga kesehatan kesehatan dalam memberikan asuhan pelayanan medis kepada pasien. Selain itu keselamatan pasien juga tertuang dalam undang-undang kesehatan, dimana terdapat pasal yang membahas secara rinci mengenai hak dan keselamatan pasien. Keselamatan pasien merupakan hal terpenting yang perlu diperhatikan oleh rumah sakit dan setiap tenaga kesehatan.

Berdasarkan hasil penelitian Rieckmann et al., (2018) diketahui bahwa keterlibatan pasien merupakan hal yang sangat penting untuk mendapatkan hasil dan sistem pelayanan kesehatan yang optimal, dalam penelitian disebutkan bahwa upaya untuk meningkatkan keterlibatan pasien terutama pasien dengan penyakit kronis, Rumah sakit perlu menyediakan fasilitas edukasi dengan menyediakan sumber terpercaya serta informasi yang akurat, untuk dapat mendorong ketaatan terapi, sehingga dapat meningkatkan quality of life. Melalui patient engagement diharapkan agar pasien dapat ikut bertanggung jawab terhadap riwayat penyakitnya.

WHO menyatakan pentingnya peran pasien dalam pengembangan pelayanan kesehatan yang lebih baik. Dengan adanya patient engagement dapat meningkatkan ketelitian dan kecermatan dokter dan tenaga medis lainnya dalam menangani pasien, sehingga dapat meningkatkan patient safety karena mempunyai pengaruh dalam memperkecil resiko kelalaian medis yang dilakukan oleh tenaga kesehatan, sehingga dapat menurunkan angka insiden keselamatan pasien. Penelitian terkait patient engagement belum banyak dilakukan, padahal hal ini sangat penting dalam upaya meningkatkan patient safety di rumah sakit.

Tujuan penelitian ini menggali persepsi pasien dan perawat terhadap patient safety sebagai upaya meningkatkan Patient Engagement sehingga pasien dapat awarness terhadap keselamatan pasien di Unit Hemodialisa Rumah Sakit. Hasil penelitian ini diharapkan dapat memberikan kontribusi signifikan terhadap pengembangan ilmu pengetahuan dan menjadi sumber informasi bagi rumah sakit yang penting sebagai upaya untuk meningkatkan keselamatan pasien.

Dari banyaknya penelitian yang dilakukan belum banyak penelitian yang mengarah pada patient engagement. Kebanyakan penelitian yang telah dilakukan merujuk pada patient safety. Oleh karena itu, dengan adanya penelitian ini, peneliti percaya bahwa keterlibatan pasien dan keluarga dapat berkontribusi dalam meningkatkan pengalaman pasien dan hasil kesehatan serta kesejahteraan pasien. mengacu pada penelitian-penelitian sebelumnya, serta adanya patient engagement, diharapkan bahwa pasien dan pekerja medis dapat dapat bekerja sama untuk meningkatkan sistem pelayanan kesehatan. 


\section{METODE PENELITIAN}

Penelitian ini menggunakan pendekatan metode deskriptif kualitatif, dikarenakan dalam penelitain ini data yang dihasilkan berupa data deskriptif yang diperoleh dari data-data berupa tulisan, kata-kata hasil wawancara mendalam yang berasal dari observasi dari sumber atau informan yang diteliti dan dapat dipercaya. Keselamatan pasien pada penelitian ini akan di fokuskan kepada ketepatan identifikasi pasien, pengurangan resiko infeksi dan komunikasi efektif.

Jenis penelitian ini adalah penelitian kualitatif dengan melakukan wawancara mendalam kepada pasien dan tenaga medis pelaksana bahkan observasi sebagai tambahan untuk menunjang hasil penelitian. Metode ini dapat menghasilkan data secara luas dan mendalam, sehingga dapat membantu dalam menyelesaikan masalah patient safety dengan meningkatkan patient engagement.

Pengumpulan data dalam penelitian diambil dari wawancara beberapa staf medis dan pasien di salah satu Unit Hemodialisis rumah sakit di kota Yogyakarta. Indonesia yang memiliki pelayanan hemodialisa dilengkapi dengan observasi lapangan pda unit tersebut. Kemudian hasil interview dan observasi dikumpulkan lalu ditarik kesimpulan sesuai dengan tujuan penelitian.

\section{HASIL PENELITIAN}

Budaya keselamatan adalah konsep dasar dalam pelayanan kesehatan dimana setiap pasien dan setiap warga negara memiliki hak untuk menerima perawatan kesehatan yang berkualitas tinggi dan dapat diandalkan. Keselamatan pasien harus selalu didahulukan ketika mengatur sistem dalam pelayanan kesehatan dimanapun, sehingga penting untuk mengenali setiap resiko dalam pelayanan kesehatan. Keselamatan pasien telah mendapat perhatian yang meningkat dalam beberapa tahun terakhir, tetapi sebagian besar penelitian fokus pada epidemiologi kesalahan dan efek samping, bukan ada praktik upaya untuk mengurangi kejadian tersebut.

Pada penelitian ini, secara keseluruhan pasien mengatakan pelayanan yang diberikan di Unit Hemodialisa cukup baik, sehingga tidak ada masukkan yang spesifik yang dibutuhkan pasien dan keluarga dalam meningkatkan keselamatan pasien. Pasien mengatakan, edukasi sering diberikan oleh tenaga medis di Unit Hemodialisa Rumah Sakit, baik itu edukasi secara langsung saat terapi cuci darah, maupun saat pertemuan di dalam forum IKADIA.

"Keramahan petugas medis memberikan kemudahan pasien dan pendamping pasien untuk terbuka kepada dokter maupun perawat, sehingga memudahkan pasien dan keluarga dalam bertanya kepada dokter dan perawat terutama jika terdapat keluhan." Pasien A

Selain itu menurut kesaksian pasien di atas, secara keseluruhan pasien mengatakan tenaga medis yang ada di Unit Hemodialisa sudah sangat perhatian dengan pasien. Pasien lain juga menuturkan bahwa:

"saya puas dengan pelayanan tenaga medis. Petugasnya ramah, selain itu mereka bekerja dengan sigap dan tanggap” Pasien B

Berdasarkan hasil wawancara dengan pasien gagal ginjal di Unit Hemodialisa Rumah Sakit di atas, didapatkan bahwa pasien dan keluarga puas dengan pelayanan yang diberikan oleh tenaga medis selain karena keramahan petugas medis, tetapi juga 
karena kinerja yang diberikan oleh tenga medis dalam memberikan pelayanan kepada pasien.

Pengalaman pasien dan keluarga berfungsi sebagai alat penting bagi rumah sakit untuk mengidentifikasi hal apa saja perlu perbaikan untuk meningkatkan kualitas pelayanan di rumah sakit. Secara umum pasien dan keluarga dapat terbuka dengan tenaga medis dan memiliki kesan pengalaman yang baik, positif dan memuaskan dengan semua fasilitas yang ada di unit HD Rumah Sakit. Dalam penelitian didapatkan rata-rata pasien yang ada di Unit Hemodialisa Rumah Sakit menyatakan bahwa sudah terlibat dalam proses keselamatan pasien. Dimana keterlibatan tersebut dinyatakan dalam hal menjaga kesehatan, mematuhi perintah dari tenaga medis baik dokter maupun perawat dan beberapa dari pasien aktif mencari informasi terkait penyakit dan pola hidup yang sehat untuk pasien dengan gagal ginjal. Informasi-informasi tersebut biasanya didapatkan melalui pencarian di internet, via Google, via grup-grup yang ada di sosial media, seperti WhatsApp, Facebook, dan lain lain.

Dari hasil wawancara ditemukan bahwa persepsi berasal dari pengetahuan dan pemahaman yang diyakini pasien dan tenaga medis, persepsi inilah yang akan menentukan sikap dalam penerapan patient safety. Persepsi perawat di Unit Hemodialisa Rumah Sakit terhadap patient safety baik meski dalam pelaksanaannya ada beberapa hal yang belum optimal seperti pemakaian gelang identitas pada pasien yang melakukan rutinitas cuci darah di Unit HD Rumah Sakit. Kurangnya sosialisasi, pemantauan dan ketersediaan gelang identitas perlu di perhatikan karena terkait dengan pemahaman dan kesadaran pasien serta tenaga medis dalam menerapkan program keselamatan pasien.

Sebagian besar perawat di Unit HD Rumah Sakit memahami prinsip dasar keselamatan pasien, perawat memiliki persepsi yang baik terhadap pedoman dan prosedur keselamatan, sikap, motivasi dan kerja sama pasien. Namun masih ada beberapa perawat yang memiliki persepsi kurang baik tentang pelaksanaan gelang identitas pasien. Hal ini dikarenakan pasien dan keluarga serta tenaga kesehatan merasa sudah saling kenal sehingga merasa tidak berbahaya jika tidak menggunakan gelang identitas di Unit HD. Padahal panduan dalam pelaksanaan patient safety telah dikemukakan secara jelas saat pelaksanaan akreditasi, hanya saja dalam implementasinya prosedur ini masih kurang diterapkan.

Berdasarkan data wawancara dengan perawat yang ada di Unit HD Rumah Sakit mengatakan telah melaksanakan tugas sesuai dengan SOP yang berlaku. Perawat juga telah berupaya untuk terus memberikan edukasi kepada pasien dan menjaga hubungan kekeluargaan antara pasien dengan tenaga medis, sebagai upaya untuk menerapkan patient safety terkait komunikasi efektif.

"Sistem kerja dan pelayan yang diterapkan di Rumah sakit ini disesuaikan dengan Standard Operating Procedure (SOP). Pasien juga telah diberi pengetahuan tentang keamanan pasien melalui komunikasi yang efektif dengan para tenaga medis”Tenaga Medis C

Sehingga, melalui edukasi dan hubungan kekeluargaan yang terjalin, diharapkan pasien dan keluarga dapat terlibat aktif dalam menjaga keselamatan pasien. Terjadinya insiden keselamatan pasien di rumah sakit akan menyebabkan menurunnya kepercayaan masyarakat terhadap rumah sakit. Ini karena rumah sakit dianggap memiliki kualitas layanan yang rendah, karena keselamatan pasien memiliki korelasi yang tinggi dengan kualitas dan citra rumah sakit. 


\section{PEMBAHASAN}

Menilai budaya keselamatan pasien adalah langkah pertama dalam proses panjang untuk identifikasi area yang perlu perbaikan yang dapat dilakukan di rumah sakit untuk mencegah kejadian tidak diharapkan/KTD, sebagai upaya peningkatan kualitas pelayanan kesehatan (Ulumiyah, 2018). Budaya keselamatan pasien dibentuk oleh sikap, kepercayaan dan pengetahuan tentang keselamatan pasien dalam suatu organisasi. Namun peningkatan keselamatan pasien membutuhkan perubahan dalam praktik aktual (Octaviani et al., 2020).

Pelayanan kesehatan merupakan suatu sistem yang sangat kompleks dan memiliki banyak multiple stakeholder dan providers. Pasien merupakan orang yang menggunakan layanan kesehatan berupa jasa medis yang memiliki peranan penting sebagai co-producer kesehatan. Pasien merupakan informan penting dalam perbaikan kebijakan, sehingga mengajak pasien berkontribusi merupakan suatu cara yang signifikan untuk dapat meningkatkan patient safety dan kualitas pelayanan kesehatan. Istilah keterlibatan pasien mengacu pada proses membangun dan memfasilitasi pasien untuk mendukung keterlibatan aktif pasien dalam perawatan kesehatan mereka sendiri (Valderas et al., 2019).

Beberapa literatur menyebutkan pasien yang memiliki penyakit kronis cenderung memiliki lebih banyak pengalaman dalam perawatan diri dan sering memiliki pemahaman yang lebih tentang keterlibatan pasien. Pasien juga menghargai, komunikasi yang baik antara pasien dan tenaga medis. Yang perlu diperhatikan adalah bahwa pengalaman dan komunikasi ini merupakan pusat konsep keterlibatan pasien. Literatur lain juga menyebutkan bahwa pengalaman pasien cenderung menyebabkan pasien lebih kritis terhadap perawatan kesehatan atau status kesehatan yang dirasakan. Hal ini pula yang menyebabkan pasien yang memiliki penyakit kronis lebih banyak memiliki pengalaman terkait status kesehatan mereka, sehingga secara tidak langsung mereka lebih mudah untuk terlibat dalam menejemen kesehatan mereka. Pasien di Unit Hemodialisa Rumah Sakit mengatakan bahwa unit ini memiliki pelayanan yang baik. Adanya fasilitas yang mendukung dan lingkungan kekeluargaan yang dirasakan pasien yang menyebabkan pasien merasa puas dengan pelayanan kesehatan yang diberikan oleh unit hemodialisa rumah sakit.

Dalam penelitian ini didapatkan bahwa meskipun pertemuan pasien dengan dokter terbatas dan singkat, namun pasien merasa puas dengan pelayanan yang diberikan di Unit Hemodialisa Rumah Sakit dikarenakan koordinasi antara perawat dengan dokter terjalin baik, sehingga pasien merasa nyaman dan aman. Pasien biasa bertanya terkait keluhan mereka ketika dokter sedang visit, akan tetapi jika keluhan tersebut harus diberikan penanganan segera maka pasien akan segera memberi tahu kepada perawat, kemudian perawat segera memberitahu dokter jaga untuk dapat di berikan pelayanan atau tindakan segera.

Budaya organisasi yang berkualitas di mana pihak rumah sakit dapat menjamin kesejahteraan stafnya dan dari hasil survei penelitian sebelumnya didapatkan bahwa kepuasan pasien berkorelasi tinggi dengan keceriaan, keramahan dan kepekaan staf (Rudyarti et al., 2017).

Tujuan dari keterlibatan pasien dan keluarga adalah untuk melibatkan semua pemangku kepentingan yang relevan dalam membangun fasilitas pelayanan kesehatan yang lebih aman, menciptakan dan mempertahankan budaya keselamatan di semua unit pelayanan kesehatan. Gerakan melibatkan pasien juga mendukung dalam hal 
memajukan agenda kualitas dan keselamatan pasien. Melibatkan pasien dalam pelayanan kesehatan merupakan hal penting untuk memberikan nilai tambah bagi publik.

Pasien memiliki persepsi yang berbeda dengan tenaga medis terkait patient safety. Sebagian besar pasien mengatakan tidak pernah mendengar patient safety. Pemahaman patient safety sendiri oleh pasien merupakan suatu hal yang berbeda dari pengertian dan pemahaman tenaga medis. Ada beberapa pasien yang mengatakan bahwa keselamatan pasien adalah usaha kesiapan dari petugas rumah sakit untuk menjaga agar tidak terjadi hal-hal yang tidak diinginkan seperti keteledoran, penanganan emergensi, tenaga medis yang perhatian terhadap pasiennya, tenaga medis yang melakukan tindakan sesuai prosedur dan SOP, menjaga kesehatan, memiliki pola hidup yang sehat, komitmen manajemen rumah sakit dalam menyediakan sarana prasarana keselamatan pasien. Hal ini menunjukkan perlu diberikan pendekatan berupa edukasi kepada pasien-pasien di Unit Hemodialisa Rumah Sakit terkait pengertian patient safety yang sebenarnya.

Pengetahuan adalah hal yang dominan dan sangat penting dalam pembentukan tindakan seseorang. Dikarenakan pemahaman pasien berbeda dengan pemahaman patient safety oleh tenaga medis professional, sehingga pasien memandang penerapan keselamatan pasien yang ada di Unit Hemodialisa Rumah Sakit baik, yakni pasien memandang wajar jika rumah sakit swasta memiliki pelayanan kesehatan yang lebih baik daripada rumah sakit negeri, pasien juga memahami bahwa penerapan keselamatan pasien dengan menjaga kebersihan, penanganan yang cepat oleh tenaga medis, keramahan dan perhatian dari tenaga medis, komitmen dari manajemen rumah sakit dalam menyediakan sarana dan prasarana.

Sikap adalah pandangan atau perasaan seseorang yang disertai dengan kecenderungan untuk bertindak terhadap sesuatu. Suatu sikap belum tentu dimanifestasikan menjadi tindakan secara otomatis. Untuk mewujudkan sikap menjadi tindakan nyata diperlukan faktor pendukung atau kondisi yang memungkinkan, misalnya fasilitas. Secara keseluruhan perawat mengatakan bahwa telah melaksanakan tindakan berupa pelayanan sesuai dengan SOP yang berlaku di unit hemodialisa Rumah Sakit. Namun, ada beberapa hal yang menyebabkan penerapan patient safety masih belum maksimal, yaitu penerapan gelang identitas masih belum maksimal, penerapan resiko jatuh juga masih belum maksimal dilaksanakan, serta terdapat responden yang mengatakan bahwa penerapan cuci tangan juga masih belum maksimal, dikarenakan sulitnya untuk menyadarkan pasien dan keluarga akan pentingnya patient safety, terutama pada pasien-pasien yang sepuh, sehingga masih perlu upaya tenaga medis untuk terus meningkatkan standar pelayanan yang akan diberikan kepada pasien di unit HD Rumah Sakit. Beberapa pasien juga masih ada yang menggunakan handbody di daerah lengan yang ada asiminore-nya saat terapi HD, sehingga memang perlu diberikan edukasi kepada pasien terkait patient safety pencegahan infeksi (Barclay \& Kiefer, 2019).

Tenaga medis juga sudah menggunakan APD yang sesuai dengan yang diterapkan di rumah sakit, seperti menggunakan baju kerja, menggunakan masker, dan menggunakan handscoone setiap melakukan tindakan. Hal ini juga telah dikonfirmasi oleh pasien gagal ginjal dan supervisi di unit $\mathrm{HD}$, bahwa tenaga medis telah menggunakan APD sesuai dengan SOP yang berlaku.

Penerapan komunikasi efektif sejauh ini berjalan dengan baik, hal ini terbukti dengan adanya hubungan ikatan kekeluargaan antara pasien dengan tenaga medis dan non medis di Rumah Sakit. Tenaga kesehatan berupaya untuk memupuk kepercayaan dengan pasien dan keluarga. Pihak manajemen rumah sakit pun sudah berupaya untuk 
menjaga kualitas pelayanan dengan selalu memberikan pelatihan rutin kepada tenaga medis nya, untuk mendapatkan informasi terbaru terkait pelayanan kesehatan yang berlaku. Hal ini sebagai upaya untuk meningkatkan kualitas SDM yang ada di Rumah Sakit.

Perawat di unit HD Rumah Sakit juga telah mengetahui aturan nasional, dan standar akreditasi terkait keselamatan pasien, namun karena ada beberapa hal pelaksanaan patient safety tidak dapat di terapkan, salah satunya karena efisiensi, pemborosan penggunaan gelang identitas, dan karena sudah saling mengenal dengan pasien beserta keluarga atau pendampingnya, karena pasien yang ada di Unit HD Rumah Sakit merupakan pasien dengan penyakit kronis, yang mengharuskan pasien untuk terapi cuci darah setiap minggunya yang sudah di lakukan selama bertahun tahun.

Definisi budaya keselamatan menurut Suharsono \& Suci (2019) menangkap sebagian besar esensinya yaitu berupa nilai nilai bersama (yang penting) dan keyakinan (cara kerja) yang berinteraksi dengan struktur dan sistem kontrol organisasi untuk menghasilkan norma perilaku. Budaya keselamatan telah menjadi salah satu pilar dalam gerakan keselamatan pasien, mengingat rumah sakit sebagai industri kesehatan yang menyediakan pelayanan jasa kesehatan, yang dianggap sebagai faktor resiko potensial yang mengancam pasien.

Pemasangan gelang identitas sangat penting untuk mengkonfirmasi identitas pasien. Kesalahan dalam identifikasi pasien dapat membahayakan pasien dalam hampir setiap aspek kedokteran klinis termasuk pemeriksaan, pemberian diagnostic, pemberian obat, dan bahkan tagihan rumah sakit. Di beberapa negara pemberian gelang identitas pasien disertai dengan menambahkan foto pasien, hal ini dikarenakan penggunaan gelang identitas merupakan langkah penting untuk mengurangi kesalahan identifikasi pasien terutama untuk pasien anak-anak dan pasien lanjut usia serta yang memiliki kebutuhan khusus (Karina \& Karyus, 2017). Sebagian besar pasien mengatakan pernah dipasang gelang identitas di unit hemodialisa Rumah Sakit dan hanya beberapa pasien yang mengatakan tidak pernah dipasang gelang identitas, pasien yang tidak pernah dipasang gelang adalah pasien HD baru di unit hemodialisa Rumah Sakit. Sebagian besar pasien juga mengatakan gelang identitas hanya dipasang di waktu tertentu saja, seperti saat ada kunjungan, akreditasi, dan visitor, atau ketika kondisi pasien lagi ngedrop, sehingga di rencanakan untuk rawat inap.

Faktor yang menyebabkan penggunaan gelang identitas tidak dilaksanakan karena adanya ikatan kekeluargaan antara pasien dengan tenaga medis baik dokter maupun perawat sehingga pasien dan tenaga medis merasa sudah saling kenal. Hal ini menyebabkan pasien dan keluarga serta tenaga medis merasa tidak berbahaya jika tidak menggunakan gelang identitas di unit HD. Beberapa pasien juga menyatakan penggunaan gelang identitas tidak efisien karena dianggap pemborosan yang hanya bisa digunakan sekali pakai saja. Pemahaman terkait gelang identitas yang salah ini harus segera di perbaiki agar pelaksanaan patient safety dapat diterapkan sehingga dapat mencegah kejadian yang tidak diharapkan / KTD.

Secara umum baik pasien maupun perawat mampu memahami tujuan dari pelaksanaan keselamatan pasien, meskipun terdapat beberapa faktor yang masih perlu dikaji untuk meningkatkan penerapan keselamatan pasien. Upaya tersebut dapat dilakukan melalui sosialisasi yang lebih sering kepada pasien dan keluarga. Sosialisasi tidak hanya dalam bentuk pertemuan rutin, tetapi juga dalam bentuk media informasi seperti leaflet, poster, atau video edukasi tentang keselamatan pasien yang ditempatkan di tempat-tempat strategis sehingga dapat dilihat oleh semua orang. Rumah sakit sudah 
memiliki poster dan leaflet enam langkah melakukan cuci tangan, dan 5 momen cuci tangan menurut WHO, yang mudah dijangkau oleh pasien dan keluarga pendamping saat melakukan cuci tangan.

Tenaga medis juga tidak lupa untuk sering mengingatkan pasien agar segera mencuci tangan ketika masuk di unit Hemodialisa Rumah sakit, ini merupakan salah satu upaya untuk mendorong pasien dan keluarga untuk mencuci tangan, sehingga dapat menurunkan resiko penularan infeksi sebagai upaya untuk meningkatkan keamanan pasien sesegera mungkin. Melibatkan pasien dalam praktik cuci tangan yang baik, diharapkan mencegah infeksi nosocomial yang didapat di rumah sakit. Dikarenakan Infeksi yang didapat di rumah sakit dapat mengakibatkan peningkatan morbiditas dan mortalitas, serta meningkatkan biaya perawatan kesehatan.

Rumah sakit telah melengkapi fasilitas yang berhubungan dengan keselamatan pasien terutama yang berkaitan dengan menanggulangi kejadian infeksi nosokomial. Hal ini terbukti bahwa berdasarkan pengamatan peneliti dan hasil wawancara terhadap pasien dan tenaga medis didapatkan bahwa akses untuk mencuci tangan baik menggunakan air mengalir di wastafel maupun menggunakan antiseptik dengan handrub mudah dijangkau oleh pasien dan tenaga medis dikarenakan handrub selalu ada di masing-masing tempat tidur atau bed pasien. Oleh karena itu dapat disimpulkan bahwa rumah sakit mendukung program keselamatan pasien, dilihat dari ketersediaan kebijakan, pedoman dan prosedur sesuai peraturan pemerintah yang mengatur pelaksanaan program keselamatan pasien, disertai dengan tersedianya fasilitas yang menunjang pelaksanaan patient safety. Penelitian sebelumnya yang dilakukan oleh Haris $\mathrm{AD}$, menyebutkan $80 \%$ akses yang mudah ke wastafel dan ketersediaan fasilitas cuci tangan menyebabkan peningkatan kepatuhan untuk mencuci tangan sebagai upaya pengendalin infeksi (Harris et al., 2020). Sarana prasaranan untuk mencuci tangan telah disediakan oleh rumah sakit, namun meskipun begitu, kepatuhan pasien dalam mencuci tangan masih dirasa kurang.

Metode untuk mengidentifikasi keterlibatan pasien, yaitu secara umum dengan menggambarkan kenyamanan pasien sebagai metode dasar yang dapat diupayakan untuk mengetahui keterlibatan pasien. Adapun metode yang biasa digunakan untuk melibatkan pasien, yang paling umum adalah focus group discussion, wawancara, dan bentuk perbuatan yang paling aktif yaitu menghadiri pertemuan rutin, (Fergusson et al., 2018) seperti pertemuan IKADIA yang diadakan rutin oleh rumah sakit, dimana pasien mengatakan pertemuan tersebut banyak memberikan manfaat sehingga pasien dan keluarga berupaya untuk terlibat dalam menjaga keselamatan pasien. Adanya IKADIA dan komunitas sesama pasien HD mengakibatkan secara tidak langsung pasien terlibat dalam kegiatan diskusi dan belajar serta berbagi informasi sesama pasien gagal ginjal, sehingga dapat memberikan banyak informasi dan motivasi kepada pasien HD dan keluarga.

Secara umum, antusias pasien dan keluarga untuk mencari informasi terkait kesehatan baik, dikarenakan pasien dan keluarga berupaya untuk hadir dimana pasien tidak hanya hadir sendiri tetapi juga mengajak keluarga pasien untuk ikut dalam pertemuan tersebut dikarenakan pasien merasa bahwa yang perlu mendapatkan informasi terkait penyakit gagal ginjal tidak hanya pasien saja, tetapi keluarga juga perlu umtuk mendapatkan pengetahuan ini karena keluarga merupakan orang yang dekat dengan pasien dan bisa menjadi pengingat bagi pasien untuk semangat dalam menjalani terapi, minum obat dan lainnya. 
Selain itu pasien dan keluarga juga merasa dengan adanya kegiatan IKADIA membantu pasien dan keluarga untuk tetap percaya diri, termotivasi, serta mendapatkan ilmu dan teman yang memiliki nasib dan perjuangan yang sama, serta menjalin ikatan hubungan kekeluargaan yang erat antar sesama pasien dan keluarga pasien, sehingga diharapkan dapat saling menguatkan, dan saling memotivasi antar sesama pasien gagal ginjal. Pasien akan sering terlibat dalam perilaku tertentu jika mereka didorong oleh tenaga medis dan jika mereka merasa interaksi antara pasien dengan tenaga medis dilakukan dengan tidak mengancam identitas dengan tenaga medis (New et al., 2019).

Berdasarkan hasil penelitian sebelumnya, menyebutkan responden yang masih memiliki motivasi buruk disebabkan oleh kurangnya kesadaran dan pemahaman tentang pentingnya keselamatan pasien karena kurangnya arahan dan pemantauan dari pengawas dan Menejemen secara langsung (Fransisca \& Darmawan, 2018). Hasil wawancara mendalam menunjukkan bahwa sampai sekarang kepala ruangan (supervisor) selalu siaga di unit hemodialisa / HD, pasien juga mengatakan bahwa kepala ruangan dengan menyebutkan nama Perawat tersebut adalah Perawat yang paling rajin dan Perawat yang paling care kepada pasien yang ada di unit hemodialisa. Secara umum responden mengatakan sangat puas dengan pelayanan yang diberikan di unit hemodialisa, sehingga tidak ada masukkan yang spesifik yang diberikan oleh responden kepada tenaga medis maupun manajemen di rumah sakit.

Sebagian besar pasien mengatakan bahwa selama melakukan cuci darah keluarga mendukung, bahkan yang berkaitan dnegan finansial. Dukungan tidak hanya support dan semangt tetapi juga finansial, baik itu dari keluarga inti, maupun keluarga besar. Dukungan keliarga sangat berarti untuk semua pasien di hemodialisa. Pendamping pasien pun mengharapkan agar pasien ini selalu sehat, selalu semangat, selalu ikhlas, tetap percaya diri, tetap optimis, selalu bersyukur kepada Allah, karena Allah tau kemampuan hambanya.

\section{SIMPULAN}

Hubungan kekeluargaan ini sangat dihargai oleh pasien dan keluarga pendamping, sehingga pasien dapat terbuka dengan tenaga medis, sehingga komunikasi efektif dapat terjalin dengan baik. Ini juga tidak terlepas dari pelayanan yang diberikan oleh seluruh tenaga medis di mana baik pasien maupun keluarga memiliki keyakinan dan kepercayaan kepada dokter dan perawat yang merawat pasien, pasien juga merasa diperlakukan dengan baik dan merasa dihormati oleh tenaga medis.

\section{SARAN}

Diharapkan untuk penelitian berikutnya dapat mengembangkan hubungan dan upaya keterlibatan pasien dalam meningkatkan pasien safety untuk dapat memenuhi sasaran pasien safety di seluruh unit yang ada di rumah sakit dengan harapan dapat menekan angka insiden keselamatan pasien.

Penelitian selanjutnya diharapkan dapat meningkatkan budaya keterlibatan pasien, sebagai upaya untuk meningkatkan pasien safety. Untuk tenaga Kesehatan, diharapkan dapat mematuhi aspek aspek dalam patient safety, dalam penelitian ini didapatkan yang belum optimal pelaksanaannya adalah patuh dalam pemasangan gelang identitas kepada pasien yang ada di unit hemodialisa. 


\section{DAFTAR PUSTAKA}

Barclay, L. J., \& Kiefer, T. (2019). In the Aftermath of Unfair Events: Understanding the Differential Effects of Anxiety and Anger. Journal of Management, 45(5), 1802-1829. https://doi.org/10.1177/0149206317739107

Fergusson, D., Monfaredi, Z., Pussegoda, K., Garritty, C., Lyddiatt, A., Shea, B., Duffett, L., Ghannad, M., Montroy, J., Murad, M. H., Pratt, M., Rader, T., Shorr, R., \& Yazdi, F. (2018). The Prevalence of Patient Engagement in Published Trials: A Systematic Review. Research Involvement and Engagement, 4(1), 17. https://doi.org/10.1186/s40900-018-0099-x

Fransisca, M., \& Darmawan, E. S. (2018). Analysis of Factors Related to Employee Behavior in Implementing Patient Safety Program at Insan Permata Woman and Child Hospital Tangerang. Journal of Indonesian Health Policy and Administration, 3(1), 17. https://doi.org/10.7454/ihpa.v3i1.2266

Harris, R. E., Stinchfield, M. J., Nystrom, S. L., McKay, D. J., \& Hariharan, I. K. (2020). Damage-Responsive, Maturity-Silenced Enhancers Regulate Multiple Genes that Direct Regeneration in Drosophila. eLife, 9(3), 1-26. https://doi.org/10.7554/eLife.58305

Karina, K., \& Karyus, A. (2017). Penatalaksanaan Holistik pada Seorang Lansia Usia 70 Tahun dengan Hipertensi Grade II Tidak Terkontrol melalui Pendekatan Kedokteran Keluarga. Medical Journal of Lampung University, 6(3), 63-68. http://juke.kedokteran.unila.ac.id/index.php/majority/article/view/1110

New, L., Goodridge, D., Kappel, J., Groot, G., \& Dobson, R. (2019). "I Just Have to Take It" - Patient Safety in Acute Care: Perspectives and Experiences of Patients with Chronic Kidney Disease. In BMC Health Services Research (Vol. 19, Issue 1, p. 199). https://doi.org/10.1186/s12913-019-4014-4

Octaviani, N., Hilda, H., \& Nulhakim, L. (2020). Evaluasi Pelaksanaan Tujuh Langkah Menuju Keselamatan Pasien di Puskesmas Loa Kulu Kabupaten Kutai $\begin{array}{lllll}\text { Kartanegara. Jurnal Kedokteran } & 30 .\end{array}$ https://doi.org/10.30872/j.ked.mulawarman.v7i2.4255

Rieckmann, P., Centonze, D., Elovaara, I., Giovannoni, G., Havrdová, E., Kesselring, J., Kobelt, G., Langdon, D., Morrow, S. A., Oreja-Guevara, C., Schippling, S., Thalheim, C., Thompson, H., Vermersch, P., Aston, K., Bauer, B., Demory, C., Giambastiani, M. P., Hlavacova, J., \& Ben-Amor, A.-F. (2018). Unmet Needs, Burden of Treatment, and Patient Engagement in Multiple Sclerosis: A Combined Perspective from the MS in the 21st Century Steering Group. Multiple Sclerosis and Related Disorders, 19, 153-160. https://doi.org/10.1016/j.msard.2017.11.013

Rudyarti, E., Sutomo, A. H., \& Surono, A. (2017). Hubungan Pengetahuan Keselamatan dan Kesehatan Kerja dan Sikap Penggunaan Alat Pelindung Diri dengan Kejadian Kecelakaan Kerja pada Pengrajin Pisau Batik di Pt. X [Universitas Gadjah Mada]. In Jurnal Kesehatan Masyarakat. http://etd.repository.ugm.ac.id/home/detail_pencarian/84254

Suharsono, R. A., \& Suci, R. P. (2019). Hubungan Budaya Organisasi, Organizational Citizenship Behavior dengan Kinerja: Pendekatan Konseptual. Jurnal Ilmu Manajemen, 5(3), 28-36. https://publishing-widyagama.ac.id/ejournalv2/index.php/jim/article/view/1793

Ulumiyah, N. H. (2018). Meningkatkan Mutu Pelayanan Kesehatan dengan Penerapan Upaya Keselamatan Pasien di Puskesmas. Jurnal Administrasi Kesehatan Indonesia, 6(2), 149. https://doi.org/10.20473/jaki.v6i2.2018.149-155 
Valderas, J. M., Gangannagaripalli, J., Nolte, E., Boyd, C., Roland, M., SarriaSantamera, A., Jones, E., \& Rijken, M. (2019). Quality of Care Assessment for People with Multimorbidity. Journal of Internal Medicine, 285(30), 289-300. https://doi.org/10.1111/joim.12881

Wulandari, I., Huriah, T., \& Sundari, S. (2020). Evaluasi Safety Attitude Culture pada Perawat di Ruang Operasi PKU Muhammadiyah Gamping. Jurnal Ilmiah Universitas Batanghari Jambi, 20(1), 253-257. https://doi.org/10.33087/jiubj.v20i1.759 